ERMIN MUHAREMOVIĆ, Ph.D. ${ }^{1}$

(Corresponding author)

E-mail: ermin.muharemovic@fsk.unsa.ba

SAMIR ČAUŠEVIĆ, Ph.D. ${ }^{1}$

E-mail: samir.causevic@gmail.com

AMEL KOSOVAC, Ph.D. ${ }^{1}$

E-mail: amelkosovac@gmail.com

JASMINA BARAKOVIĆ HUSIĆ, Ph.D. ${ }^{2}$

E-mail: jasmina_barakovic@yahoo.com

${ }^{1}$ Faculty of Traffic and Communication

University of Sarajevo

Zmaja od Bosne 8, 71000 Sarajevo

Bosnia and Herzegovina

${ }^{2}$ Faculty of Electrical Engineering

University of Sarajevo, Zmaja od Bosne bb

71000 Sarajevo, Bosnia and Herzegovina
Transport Logistics

Review

Submitted: 12 Dec. 2019

Accepted: 16 July 2020

\title{
COST AND PERFORMANCE OPTIMISATION IN THE TECHNOLOGICAL PHASE OF PARCEL DELIVERY - A LITERATURE REVIEW
}

\begin{abstract}
The present review paper provides a systematic insight into the studies published so far when it comes to the research on the cost and performance optimisation in the parcel delivery phase. Globalisation, as well as the new trends, such as selling online, directly influences the demands for the delivery of goods. Demand for the delivery of goods proportionally affects the transport prices. A great majority of deliveries is carried out in densely populated urban areas. In terms of costs, the greatest part in the courier organisations costs is observed in the technological phase of parcel delivery, which is at the same time the least efficient. For that reason, significant improvement of performance and cost optimisation in the very delivery phase is a rather challenging field for the researchers. New algorithm-based technologies, innovations in the logistics and outsourcing of individual technological phases are ways by means of which one strives to enhance the delivery efficiency, to improve performance and quality, but also - to optimise the costs in the last phase of delivery. The aim of the present paper is to offer a systematic review into the most recent research in the field of technology, innovations and outsourcing models with the aim of reducing the cost and enhancing the productivity and quality in parcel delivery.
\end{abstract}

\section{KEYWORDS}

optimisation; costs; performances; delivery; innovations; technology; outsourcing.

\section{INTRODUCTION}

The traffic system as an industry being involved in the everyday life of people and the society as a whole affects social, economic, ecological, political and cultural activities in its surroundings. In most countries, it plays a significant role in the economic and social life as well as on the market. It is estimated that in 2016 the postal sector in the European Union, which encompasses mail, parcel and express delivery services, made a total profit of 90 million euro [1].

Each of the technological phases of postal traffic produces certain costs which are at the end summed and comprise the majority of the overall operational costs, which, together with other costs, comprise the total costs of a postal organisation.

Each technological phase of postal traffic is an individual phase, which is why the costs are treated, analysed and calculated separately [2]. The demand for postal services is not equal throughout the year, this being the reason why it is quite important to synchronize the demands and oscillations within time periods, i.e. seasonal trends, as they are driving the capacities thus creating the direct costs. Postal organisations may be a part of transport or logistic organisations. In the logistic processes, the postal companies in the last phases of the logistic process resort to the so-called last-mile-delivery phase. 
Postal organisations try to optimise their costs in different ways when it comes to the delivery phase, the proportion of which is $53 \%$ [3] in the overall operational costs. The authors [4] provide an illustration of the rise in volume on the Korean market in terms of express delivery and a proportional decrease in prices per item delivered. In the period of 12 years, the number of parcels increased from 52 million to 2 billion and 47 million. Such trends in the volume increase and the decrease in prices have direct effect on the courier services and their costs. Owing to the increase in the delivery of parcels on the express delivery market and the proportional decrease in the prices per transport item [4], the courier organisations are under an increasing pressure due to the costs causing an increase in the delivery items. The transport price is not increasing proportionally with the volume; the price per parcel in 2004 was $3.291 \$ /$ per parcel, whereas in 2016 , the price dropped to $\$ /$ parcel [4], while the costs are increasing faster than the profits causing a decline in the profitability of the organisation.

To optimise costs, the companies are trying to adapt in the way that they resort to certain restructurings, introducing contemporary technologies and innovations, optimising routes of delivery vehicles and outsourcing various segments of technological process.

A majority of studies related to the organisations dealing with parcel delivery are aimed at cost reduction through various vehicle route optimisations or at introducing contemporary technologies and innovations as well as cost reduction by means of various network distances, etc. This claim has been confirmed by the authors who did research [4] on the price and collaboration in the last-mile delivery.

The aim of the present paper is to present a review of the research so far and give answers to questions such as whether there are innovations, algorithms and outsourcing models in the optimisation of costs, performance and quality in the technological phase of parcel delivery that may be directly linked to profit.

\section{METHODOLOGY}

This part of the paper discusses the methodological approach to the present research. The review of the sources dealing with the optimisation of costs and performance in the technological phase of parcel delivery based on logistic technological innovations, algorithm and outsourcing is presented using
SLR (Systematic Literature Review). The aim of systematic literature reviews is to identify scientific papers, critically assess them and incorporate the relevant studies dealing with the research question. Papers were collected through extensive searches of electronic databases such as Web of Science, Scopus, IEEExplorer, Researchgate, ScienceDirect, Google Scholar, Elsevier, Transport Research International Documentation. The databases used are most relevant to the research area.

For the purposes of the present paper, a range of various key words/terms has been searched, such as: 'last mile delivery cost', 'outsourcing model', 'outsourcing delivery', 'reduce delivery costs using drones', 'drone delivery', 'vehicle routing problem', 'reduce transportation costs', 'information and communication technologies', 'last mile costs', 'innovation vehicle', 'autonomous vehicle delivery', 'outsourcing shipment delivery'. A combination of key words has also been applied as a criterion in the research by means of Booles' operations OR and AND (e.g. last AND mile AND delivery, delivery OR cost).

The search was limited to the English-language papers.

To narrow the number of papers during the database search, the criteria were introduced such as:

- focus on journals and conference papers (not on presentations, grey literature, lectures);

- focus on pick-up and delivery shipments (not on warehouse and sort);

- focus on using outsourcing in logistics to pickup and delivery (not on general outsourcing in IT, rent, warehouse, etc.);

- focus on innovations that aim at using logistics (not on innovations that have a goal of widespread use);

- focus on algorithms used to optimize the movement of a delivery vehicle (not on algorithms used to optimize the movement of passenger vehicles).

\section{ANALYSIS}

The research conducted in this paper has been divided into two parts for the sake of structure and clarity: (1) research of papers dealing with the optimisation of vehicle movement and costs, performance and quality, based on technology and innovation, and (2) research of papers dealing with cost, performance and quality optimisation, based on outsourcing models. 


\subsection{Papers based on technology and innovation}

The technology-based approach is based on introducing contemporary devices and innovations, intelligent transport systems and devices into vehicles which are based on algorithms of the vehicle movement optimisation and logistic innovations with the aim of reducing the costs, improving the quality and delivery performance.

Table 1 illustrates a review of the papers analysed on the utilization of various algorithms to optimise vehicle movement in pick-up and delivery.

The papers dealing with the optimisation of vehicles and their utilization in postal traffic use different input parameters for the reduction of vehicle movement costs.

Intelligent systems for a more efficient managing of the pick-up and delivery operations based on the Geographic Information System (GIS) [5], Global Positioning System (GPS) and wireless communication technologies are applied in order for various subsystems to be developed such as: systems for planning the pick-up and delivery routes, system for tracking pick-up and delivery, and the executive pick-up and delivery system.

The system for planning pick-up and delivery generates routes and schedules for pick-up and delivery by means of GIS and optimisation techniques. The cost generated by vehicles in the route of pickup and delivery is reduced by optimisation [6].

The pick-up and delivery system [7] monitors the current positions of vehicles and actual pick-up and delivery results in comparison with the planned sequence, routes and times, whereas the executive system transmits information for the position of vehicles, transmits the actual data and the results of pick-up by means of the global positioning system and wireless communication technologies [8].

Assessing efficient routes for deliverers in inner parts of the urban areas is becoming more challenging due to the increasing congestions. New technologies allow a reservation of delivery zones to streets in order to reduce the waiting time and circulation. When planning the delivery process, one has to take the driving into account as well as the pedestrian lanes to the recipient door in order to optimise the activities and reduce the costs. For this purpose, two-tier optimisation models have been developed in order to determine the most convenient route for the minimisation of operational and ecological costs. A genetic algorithm has been suggested for assessing the optimal delivery solutions [9]. In order to reduce the costs in the collection and delivery in logistic systems with cross-docking, the authors [10] have developed a system based on the branchand-price algorithms. This model optimises the vehicle movement and directly reduces the operational costs related to parcel pick-up and delivery.

The authors [11] form a model environment for vehicle movement which encompasses relevant features of the road network, including the basic set of road rules. They also define a stochastic version of the model in which the pick-up and delivery are conducted in pairs on random nodes within the network and on the network nodes.

Table 1 - A review of algorithm-based papers

\begin{tabular}{|c|c|c|c|c|c|c|}
\hline \multirow[b]{2}{*}{$\begin{array}{l}\text { Type of } \\
\text { access }\end{array}$} & \multirow[b]{2}{*}{ Paper, Year } & \multirow[b]{2}{*}{ Input variables } & \multicolumn{3}{|c|}{ Aim } & \multirow[b]{2}{*}{ Used methods } \\
\hline & & & $\begin{array}{c}\text { Vehicle } \\
\text { movement } \\
\text { optimisation }\end{array}$ & $\begin{array}{c}\text { Cost } \\
\text { management }\end{array}$ & $\begin{array}{l}\text { Performance } \\
\text { and quality }\end{array}$ & \\
\hline \multirow{4}{*}{ 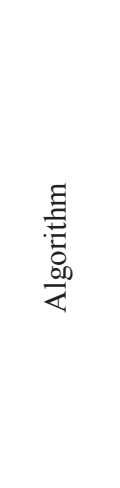 } & [8], 2018 & $\begin{array}{l}\text { Postal offices, time frame- } \\
\text { work, GIS time/distance, } \\
\text { request for pick-up and } \\
\text { delivery }\end{array}$ & $\mathrm{x}$ & & & $\begin{array}{l}\text { Pick-up and delivery } \\
\text { sequence planning } \\
\text { algorithm and address } \\
\text { correction algorithm }\end{array}$ \\
\hline & [9], 2018 & $\begin{array}{l}\text { Walking speed, average driv- } \\
\text { ing speed, emission costs, } \\
\text { costs of work }\end{array}$ & $\mathrm{x}$ & $\mathrm{x}$ & & Walking gait algorithm \\
\hline & {$[10], 2013$} & $\begin{array}{l}\text { Number of routes, number of } \\
\text { stops, cost per transport unit }\end{array}$ & & $\mathrm{x}$ & & Branching algorithm \\
\hline & {$[11], 2012$} & $\begin{array}{l}\text { Number of stops, length of } \\
\text { routes }\end{array}$ & $\mathrm{x}$ & $\mathrm{x}$ & & Stitching algorithm \\
\hline
\end{tabular}


By using the defined models, the authors provide a polynominal-time algorithm for solving the optimal number of pick-ups and deliveries. The simulation conducted and presented in the paper on the basis of 50 pick-ups and deliveries illustrates that it is possible to reduce the cost by $10 \%$ using the suggested vehicle movement algorithm.

These papers do not take into consideration the influence of optimisation and vehicles movement on the performances and the quality of tasks performance through the process of parcel pick-up or delivery. Table 2 gives a review of papers based on logistic innovations.

In Table 2, the logistic innovations have been classified into four categories, i.e.: innovative vehicles (van, heavy-goods bus, electric vehicles, electric bicycles, cargo bikes, etc.), parcel lockers (lockers for delivery and pick-up, special boxes), autonomous aerial vehicles - drones for parcel delivery to the recipient address and autonomous land vehicles, i.e. delivery robots.

Other papers give a review on the combination of various innovations with the aim of more efficient parcel delivery services.

The innovations and technologies researched in the paper [12] are classified into five categories: innovative vehicles, proximal stops or nodes, collaborative and co-operative urban logistics, optimisation of traffic management and routing, innovations in public policies and infrastructures.

The model based on technology and warehouse re-organisation called 'innovative logistics model with a container solution' is described in paper [13]. The model is applicable to deliveries in urban areas

Table 2 - A review of papers based on technology and innovations

\begin{tabular}{|c|c|c|c|c|c|c|c|c|}
\hline \multirow[b]{2}{*}{ 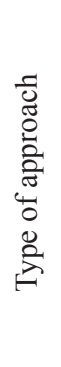 } & \multirow[b]{2}{*}{ Paper, year } & \multicolumn{4}{|c|}{ Innovation utilized } & \multicolumn{3}{|c|}{ Aim } \\
\hline & & 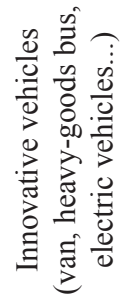 & 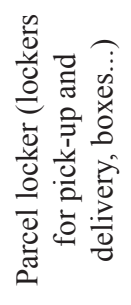 & 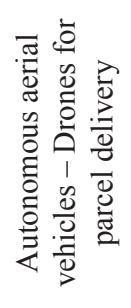 & 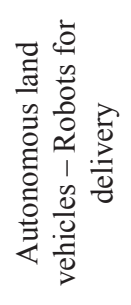 & 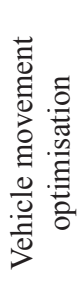 & 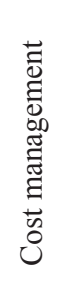 & 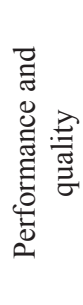 \\
\hline \multirow{20}{*}{ 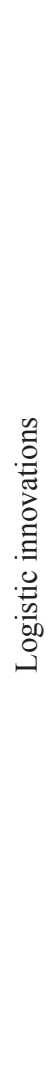 } & [13], 2012 & $\mathrm{x}$ & $\mathrm{x}$ & & & & $\mathrm{x}$ & $\mathrm{x}$ \\
\hline & {$[14], 2016$} & $\mathrm{x}$ & & & & & $\mathrm{x}$ & $\mathrm{x}$ \\
\hline & {$[15], 2016$} & $\mathrm{x}$ & & & & & & \\
\hline & {$[16], 2017$} & $\mathrm{x}$ & & & & & & \\
\hline & {$[17], 2014$} & $\mathrm{x}$ & & & & & $x$ & \\
\hline & {$[18], 2017$} & $\mathrm{x}$ & & & & & & \\
\hline & {$[11], 2018$} & & $\mathrm{x}$ & & & & $\mathrm{x}$ & $\mathrm{x}$ \\
\hline & {$[20], 2016$} & & $\mathrm{x}$ & & & \multirow{5}{*}{$\mathrm{x}$} & \multirow{5}{*}{$\mathrm{x}$} & \multirow{5}{*}{$\mathrm{x}$} \\
\hline & {$[21], 2019$} & & $\mathrm{x}$ & & & & & \\
\hline & {$[22], 2018$} & & $\mathrm{x}$ & & & & & \\
\hline & {$[23], 2016$} & & $\mathrm{x}$ & & & & & \\
\hline & [24], 2018 & $\mathrm{x}$ & & $\mathrm{x}$ & $\mathrm{x}$ & & & \\
\hline & {$[25], 2018$} & $\mathrm{x}$ & & $\mathrm{x}$ & & $\mathrm{x}$ & & $\mathrm{x}$ \\
\hline & {$[21], 2019$} & & $\mathrm{x}$ & & & $\mathrm{x}$ & $\mathrm{x}$ & $\mathrm{x}$ \\
\hline & {$[26], 2019$} & & & $\mathrm{x}$ & & \multirow{6}{*}{$\mathrm{x}$} & & \multirow{6}{*}{$\mathrm{x}$} \\
\hline & {$[27], 2016$} & $\mathrm{x}$ & & $\mathrm{x}$ & & & & \\
\hline & {$[28], 2017$} & & & $\mathrm{x}$ & & & & \\
\hline & [29], 2017 & $\mathrm{x}$ & & $\mathrm{x}$ & & & & \\
\hline & {$[30], 2008$} & & & $\mathrm{x}$ & & & & \\
\hline & $\begin{array}{l}{[31], 2018} \\
{[32], 2018}\end{array}$ & $x$ & & $\mathrm{x}$ & & & & \\
\hline
\end{tabular}


and utilizes two types of vehicles: a heavy-goods bus that loads the parcels in the warehouse and a van for deliveries of low-cost and high eco-characteristics.

The vehicles are interoperable, so it is easy to transfer the containers from heavy-goods buses onto vans. The special containers are reloaded onto vans that drive to the final destination. This method presents an improved chain of delivery in which the delivery performance is enhanced, the number of miles covered reduced, as well as the emission of pollutants.

In recent years, the freight transport and delivery in urban areas have become key activities supporting industrial and social development. At the same time, awareness of the improvement of mobility in urban areas is being raised, which allows these activities to be more sustainable from the economic and ecological aspect. The need to improve the efficiency of delivery while reducing marginal profits has resulted in identifying new possibilities of delivery by means of new technologies and innovations.

The introduction and influence of innovative freight bikes on delivery costs, performance and cost calculation in the delivery and pick-up process in central urban areas is analysed in paper [14].

At present, the electric vehicles are considered to be a serious alternative to conventional vehicles $[15,16]$ for the delivery in central urban areas [17]. From the ecological aspect, these vehicles have zero toxic gas emissions which is one of the additional advantages to conventional vehicles running on gas [18].

The utilization of electric vehicles in parcel delivery in central urban areas will exclusively depend on the circumstances of the country. Such delivery method is planned to be implemented in [19]. Electric vehicles are more cost-efficient and more efficient in terms of the gas expenses, the amount of carbon dioxide emitted and the forest area necessary to absorb $\mathrm{CO}_{2}[18]$.

In paper [20], parcel delivery is divided into five points: reception box, collection point, post office, attended home delivery and unattended home delivery. Each point is presented and compared, and new technology trends which may be utilized to improve performance and the quality of the delivery suggested.

E-commerce parcel delivery in the Business to Customer segment is based on the delivery to the recipient home address. An increasing demand for deliveries of such parcels has direct influence on the problems of traffic and congestion in central urban areas, which is the reason why delivery companies have created innovative parcel lockers. This innovation is more ecologically acceptable as it reduces the movement of vehicles in central urban areas on the one hand, while on the other, it gives flexibility to the service users. Paper [21] analyses the influence of delivery by comparing the classic delivery system (60 parcels per day and $150 \mathrm{~km}$ distance covered) and the delivery service with innovative parcel lockers (600 parcels per day and $70 \mathrm{~km}$ distance covered).

Such a delivery method has a double positive effect: reduction in the emission of harmful gases and the reduction of parcel transport costs. The lockers or points for the pick-up and delivery of parcels in the same-day-delivery system display a range of advantages for the customer [22-24]. On the basis of the analysis of the numbers of pick-ups and deliveries, these points are installed in the vicinity of the users' homes [23].

The pick-up and delivery points have also numerous advantages when it comes to delivery companies. The vehicles deliver a greater amount of parcels to the automated station and not to the time-consuming and often unpredictable service of individual customers [25]. Another great advantage of pick-up points when it comes to pick-up is that the delivery may be conducted by means of autonomous vehicles. Many companies invest significant resources in the autonomous land vehicles (robots) and autonomous air vehicles (drones).

Autonomous robots for parcel delivery [26] are innovations using heavy-goods buses or vans from which small robots may be launched to perform individual deliveries, i.e. one item per one customer. The freight vehicle is loaded in a decentralized warehouse with robots which are then launched in central urban areas from where the robots perform deliveries to the recipient addresses. After the delivery, the robots autonomously return to the closest robot warehouse, i.e. the freight vehicle. Such a delivery concept requires the recipient of the delivery to be at home in order to unlock the freight robot and receive the delivery. The recipients who are not at home have the option to postpone the robot, i.e. the delivery. Such a concept is similar to the concept of delivery by drones, which is confirmed in paper [26]. On the other hand, drones can fly over buildings and have greater speed, while autonomous robots may move at a typical walking speed and use 
the paths people use. The drone delivery may be performed in the case the recipient of the delivery is not at home; the drone may unload the item onto the recipient's balcony. The research results show that it is necessary to weigh investment costs for a denser network of robot depots and safety profits for slower robots in order to compare them against the delivery performance.

The study which has been conducted shows that decentralized robot depots greatly contribute to a successful delivery process and also shows that the freight vehicle fleet may be significantly reduced if autonomous robots support the delivery process. The main advantage of autonomous vehicles is that they are, in terms of comparison, more cost-efficient due to an increasing demand for drivers and higher salaries [22].

The evolution of pilotless aerial vehicle technology during the last decade has opened doors of opportunity to numerous innovative solutions and applications in transport/logistics [27-29]. The problem of drone-routing [30] in the process of pick-up and delivery may be observed as a mixed/ whole number programme [27,31], which minimises the routing costs of vehicles and pilotless aerial vehicles in order to serve all users.

More recent research explores the integrated vehicle-drone system [27, 29, 32]. The system generally comprises vehicles (trucks or vans) which transport pilotless vehicles (robots and drones) from their warehouses to the neighbourhood where the pilotless vehicles are shipped to carry out numerous pick-up and delivery tasks [27].

It has been estimated that such a system doubles the delivery performance efficiency [27], which is why the number of parcels in the pick-up and delivery process per one working shift, in comparison to a typical conventional delivery, is doubled, thus allowing for an increase in the delivery performance and a decrease in the production costs.

Most research on the introduction of logistic innovations into the technological process of parcel delivery does not take into account the costs produced by such innovations but on measuring performance and quality.

\subsection{Papers based on outsourcing models}

The approach through outsourcing is based on introducing the models of cost calculation and measuring performance and the quality of external service providers by means of contracts that are based on partnership and long-term co-operation. Such approach allows companies to variablise their fixed costs, reduce the capital costs, improve the quality and transport capacities, increase profitability and productivity, and reduce the costs and innovation risks [33].

There are several studies based on outsourcing services in the technological phase of parcel delivery in courier services which is why the models and the principle may be found in only few papers in the indexed databases [4]. Study [34] is on the number of papers published in the period from 1996-2017 in relevant international journals on outsourcing in the field of: logistics, the supply chain, managing the supply chain, managing the operations, transport, distribution and marketing.

The result of the research has shown that 41 papers were published during the research process, six of which were papers on the reduction of costs and improvement of services through outsourcing in the delivery.

Table 3 illustrates a review of the papers based on outsourcing.

The input parameters are structured following four criteria used in the researched papers on the outsourcing models:

- time, which corresponds to the time spent on route, working hours, shipping transit time...;

- volume, which corresponds to the quantity, type, weight and packaging of the parcels;

- vehicles and drivers - comprises factors such as: kilometres covered, speed of movement, the type of vehicle used for the delivery, fixed costs of the vehicle, the number of stops the vehicle makes during the working day or hour, emissions, the cost of the driver's work, etc.;

- other parameters which are neither part of the volume, vehicle, driver or the time categories but take the following criteria into account: the number of recipients, reputation, experience of subcontactors, relationship with the customers, extracted average variant, Cronbach's alpha, the city and the size of the city, the population, restrictions, etc.

A simplified model of outsourcing calculation costs uses the following variables: kilometres covered, the weight of the goods, the average speed of vehicle movement, the emissions factor and the externalities unit costs. Such a simplified model may be used when assessing external expenditures when delivering in central urban areas $[12,35]$. 
Table 3 - A review of outsourcing-based papers

\begin{tabular}{|c|c|c|c|c|c|c|}
\hline \multirow[b]{2}{*}{ Paper, year } & \multicolumn{4}{|c|}{ Input variables } & \multicolumn{2}{|c|}{ Aim } \\
\hline & 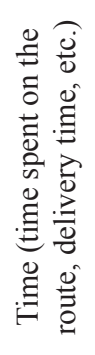 & 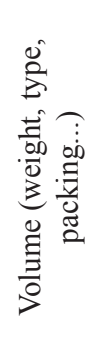 & 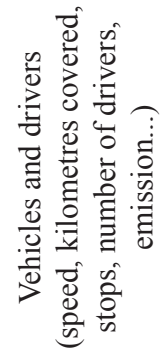 & 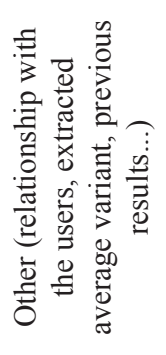 & 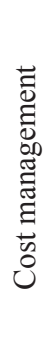 & 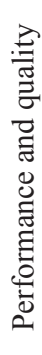 \\
\hline$[34], 2017$ & & \multirow{2}{*}{$\mathrm{x}$} & \multirow{2}{*}{$\mathrm{x}$} & & \multirow{2}{*}{$\mathrm{x}$} & \\
\hline$[12], 2018$ & & & & & & \\
\hline$[35], 2018$ & & & $\mathrm{x}$ & & $\mathrm{x}$ & \\
\hline$[36], 2014$ & $\mathrm{x}$ & & $\mathrm{x}$ & & $\mathrm{x}$ & \\
\hline [37], 2013 & & & & $\mathrm{x}$ & & $\mathrm{x}$ \\
\hline [38], 2008 & $\mathrm{x}$ & & $\mathrm{x}$ & & $\mathrm{x}$ & \\
\hline [39], 2000 & $\mathrm{x}$ & & & & & $\mathrm{x}$ \\
\hline [4], 2018 & \multirow{2}{*}{$\mathrm{x}$} & & & & \multirow{2}{*}{$\mathrm{x}$} & \multirow{2}{*}{$\mathrm{x}$} \\
\hline$[40], 2003$ & & & & & & \\
\hline$[41], 2016$ & $\mathrm{x}$ & & $\mathrm{x}$ & & & $\mathrm{x}$ \\
\hline [42], 2012 & $\mathrm{x}$ & & $\mathrm{x}$ & & $\mathrm{x}$ & \\
\hline [43], 2012 & & & & \multirow{2}{*}{$\mathrm{x}$} & \multirow{2}{*}{$\mathrm{x}$} & \multirow{2}{*}{$\mathrm{x}$} \\
\hline$[44], 2017$ & & & & & & \\
\hline$[12], 2016$ & & $\mathrm{x}$ & $\mathrm{x}$ & & $\mathrm{x}$ & $\mathrm{x}$ \\
\hline$[45], 2018$ & $\mathrm{x}$ & $\mathrm{x}$ & $\mathrm{x}$ & $\mathrm{x}$ & $\mathrm{x}$ & \\
\hline
\end{tabular}

In paper [36] the authors analyse the influence of increasing demands on the courier network structure in terms of reducing the costs of pick-up, delivery and sorting. The paper analyses the influence of the demands and gives a review of transport costs for different types of the distribution network. The paper also provides a model for cost calculations in transport on the basis of the kilometres covered.

The five fundamental aspects for the technological phase of parcel delivery [37] are: the level of customer service, safety and type of delivery, geographical area, the market level and population density, the vehicle fleet used, the technology and the very influence on the environment. These aspects directly influence the costs produced by the technological phases of parcel pick-up and delivery.

Furthermore, the authors of the paper have developed a model for parcel delivery as a simulation of delivery costs. The costs have been calculated after time, distance, and the number of route stops were taken into consideration [37]. With the aim of a better quality co-operation, performance and quality, modelling of outsourcing may be done through partnership and the relationship between the contracting parties [38].

The so-called Transaction Costs Theory (TTC) has been introduced based on the ex-ante and expost transaction costs for partnerships. The transaction costs theory tries to forecast which activities may be externalised and which activities may be done through market exchange.

Paper [38] provides a conceptual outsourcing model based on the partnership relationships through: reputation, experience, previous results, investment in communication and the relationship with end customers.

Through everyday fluctuations of volume, postal organisations face problems related to planning capacities for parcel delivery and pick-up as they are limited by the time schedules in the overall technological process. The operational costs, the performance and quality in pick-up and delivery to a great extent depend on the quality of capacity planning and the way business is organised. In 
order to avoid problems related to vehicle routing, paper [39] proposes a solution with the possibility of outsourcing.

The quality and performances are very important for any postal organisation as it is in this way that the demand is simulated, the price of the services increased and the profit enhanced. The model is based on finding the optimal level of performances for a service in the context of the delivery time. The model gives explicit compromises between the guaranteed delivery deadline and the costs arising from the services such as late deliveries [40].

Certain authors [4] propose an outsourcing model based on parameters such as: working hours during the day, average delivery time [41] according to the delivery service for the region, etc. This means that the outsourcing cost in the delivery for each region depends on the average delivery time, which is in the model expressed by means of the (delivery) market density function.

The model which assesses the operations of the pick-up and delivery within the outsourcing conditions proposes certain parameters through which it would be possible to follow external organisation in order to monitor the performance and quality for the execution of tasks. These parameters are: Productivity Key Performance Indicators (PKPI) and Quality of services Key Performance Indicators (QKPI) [42].

Paper [43] proposes four simple time schemes for determining the price of parcel pick-up (differential and even price) along with the corresponding optimal parcel consolidation cycle length.

These models pertain to the time intervals for transit time performance and its influence on defining the price of the parcel but also defining the price of the company that carries out the goods pick-up process. These methods may be applied to delivery as well.

The authors $[44,45]$ divide the construction of outsourcing into two concepts. The first one is the basic model ("Basic") which has positive effects on the cost only, whereas the advanced model ("Advanced") has effects on the costs and delivery performance. The models are based on the correlation of variables: extracted average variant, the construct reliability and Cronbach's alpha by means of standard deviation.
The authors introduce a classification of subcontractors to 'traditional' and 'green' ones [14]. In such a way, the subcontractors are classified also on the basis of the emission costs and the pollutants they produce. The paper gives a model of cost calculations on the basis of time spent per stop but also measures certain performances and the quality of delivery and pick-up. Of course, this model takes only small parcels into consideration, i.e. small 0-6 kg parcels.

Paper [46] provides a mathematical model for the calculation of the costs in the case of alternative solutions for pick-up and delivery, based on the logistics process variables, the attributes of the recipient and local characteristics of the city.

Table 3 illustrates a review of the research papers done on the outsourcing models with input variables used for attaining the goal of reducing delivery costs, monitoring and improving performances and quality.

\section{CONCLUSION}

In the present paper, 46 papers on the last phase of parcel delivery have been analysed. Although these references cover the field of technology, innovations and outsourcing models, there are still significant challenges in terms of costs, quality and performances in the parcel delivery process. From the authors' perspective, the algorithms utilized for the vehicle movement optimisation have not been sufficiently researched or adjusted to the branch of postal traffic, i.e. the phase of parcel delivery, as they do not take into consideration the factors that are directly correlated to the parameters such as the volume weight, the peculiarities of parcel delivery, the conditions under which a parcel may be delivered, the delivery time intervals, etc. All these factors influence the very profit of the organisation.

The innovations which utilize autonomous vehicles have not solved the problem of how this may be incorporated in the delivery phases due to their limits in comparison to conventional vehicles with drivers. It is also important to stress the problems arising during the delivery in the cases when the user is not at the address, the infrastructural limitations when it comes to delivery by autonomous vehicles, etc.

All the innovations and technologies mentioned used in the parcel delivery have both advantages and disadvantages which may be observed as challenges for the researcher. The papers exploring innovations 
do not take into consideration the parameters linked to profits, which is why there are challenges in this area in terms of linking the innovation costs and the profits gained.

A majority of researchers focus on new technologies and innovations, whereas fewer opt for the studies in the field of outsourcing by means of which it is possible to reach an optimisation of costs, enhance productivity and quality in the last phase of the delivery on the basis of partnership contract and long-term co-operation.

It has been assessed that there is a need to do further research on the outsourcing model in the parcel delivery phase which would be adjusted to those factors which have direct influence on the costs, profits, quality, and delivery performance.

\section{Dr ERMIN MUHAREMOVIĆ ${ }^{1}$}

E-mail: ermin.muharemovic@fsk.unsa.ba

Dr SAMIR ČAUŠEVIĆ ${ }^{1}$

E-mail: samir.causevic@gmail.com

Dr AMEL KOSOVAC ${ }^{1}$

E-mail: amelkosovac@gmail.com

Dr JASMINA BARAKOVIĆ HUSIĆ 2

E-mail: jasmina_barakovic@yahoo.com

${ }^{1}$ Fakultet za saobraćaj i komunikacije,

Univerzitet u Sarajevu

Zmaja od Bosne bb, 71000 Sarajevo

Bosna i Hercegovina

${ }^{2}$ Elektrotehnički fakultet, Univerzitet u Sarajevu

Zmaja od Bosne bb, 71000 Sarajevo

Bosna i Hercegovina

\section{OPTIMIZACIJA TROŠKOVA I PERFORMANSI U TEHNOLOŠKOJ FAZI DOSTAVE PAKETA - PREGLED LITERATURE}

\section{SAŽETAK}

Ovaj rad daje sistematičan pregled objavljenih radova o istraživanju optimizacije troškova i performansi u fazi dostave paketa. Globalizacija kao i novi trendovi kao što je online prodaja direktno utječu na povećanje potreba za dostavom robe. Potražnja za isporukom robe proporcionalno utječe na cijene prijevoza. Većina dostava se obavlja u gradskim zonama sa velikom gustinom naseljenosti. Gledajući sa troškovne strane, najveći udio u troškovima kurirskih organizacija ima tehnološka faza dostave pošiljaka, koja je ujedno i najmanje učinkovita. Iz tog razloga je značajno poboljšanje performansi i optimizacija troškova u samoj fazi dostave te vrlo izazovno područje za istraživače. Nove tehnologije bazirane na algoritmima, inovacije u oblasti logistike kao i outsourcing pojedinih tehnoloških faza su načini kojim se pokušava povećati učinkovitost dostave, poboljšati performanse $i$ kvaliteta, ali i optimizirati troškove u zadnjoj fazi dostave. Cilj rada je dati sistemski pregled najnovijih istraživan- ja u oblasti tehnologije, inovacija i modela outsourcinga sa ciljem smanjenja troškova, povećanja produktivnosti i kvalitete u dostavi pošiljaka.

\section{KLJUČNE RIJEČI}

optimizacija; troškovi; performanse; dostava; inovacije; tehnologija; outsourcing.

\section{REFERENCES}

[1] Almqvist M, Basalisco B, Apon J, Okholm B, Cerpickis M, Facino M. Main Developments in the Postal Sector (2013-2016); 2018. DOI: 10.2873/51951

[2] Savelsbergh MWP, Sol M. The General Pickup and Delivery Problem. Transportation Science. 1995;29(1): 1729. DOI: $10.1287 /$ trsc.29.1.17

[3] Ding Z. Evaluating Different Last Mile Logistics Solutions. Master thesis. University of Gävle, Faculty of Engineering and Sustainable Development; 2014. Available from: http://www.diva-portal.org/smash/get/ diva2:763544/FULLTEXT01.pdf

[4] Ko SY, Cho SW, Lee C. Pricing and collaboration in last mile delivery services. Sustainability. 2018;10: 4560. DOI: $10.3390 /$ su10124560

[5] Čaušević S, Deljanin A, Begović M, Deljanin E. Potentials and advantages of applying geographic information systems in various fields of traffic engineering. $5^{\text {th }}$ International Conference on Road and Rail Infrastructure; 2018. p. $1285-90$

[6] Deljanin A, Colakovic A, Muharemovic E. Rationalization of Transport of Postal Shipment using GPS/RFID Technologies in Bosnia and Herzegovina. Suvremeni Promet - Modern Traffic. 2014;34(1-2): 26-31.

[7] Deljanin A, Kosovac A, Muharemović E. Use of ITS System as a Track\&Trace in Express Delivery in Bosnia and Herzegovina. Suvremeni Promet - Modern Traffic. 2017;37(1-2): 30-5.

[8] Jung H, Lee K, Chun W. Integration of GIS, GPS, and optimization technologies for the effective control of parcel delivery service. Computers and Industrial Engineering. 2006;51(1): 154-62. DOI: 10.1016/j.cie.2006.07.007

[9] Thompson RG, Zhang L. Optimising courier routes in central city areas. Transportation Research Part C: Emerging Technologies. 2018;93(October 2017): 1-12. DOI: $10.1016 / j . t r c .2018 .05 .016$

[10] Santos FA, Mateus GR, Da Cunha AS. The pickup and delivery problem with cross-docking. Computers and Operations Research. 2013;40(4): 1085-93. DOI: 10.1016/j.cor.2012.11.021

[11] Treleaven K, Pavone M, Frazzoli E, M. P. Models and Asymptotically Optimal Algorithms for Pickup and Delivery Problems on Roadmaps. In: Proceedings of the 2012 IEEE $51^{\text {st }}$ IEEE Conference on Decision and Control (CDC); 2012. Available from: http://arxiv.org/ abs/1202.1327

[12] Ranieri L, Digiesi S, Silvestri B, Roccotelli M. A review of last mile logistics innovations in an externalities cost reduction vision. Sustainability (Switzerland). 2018;10: 782. DOI: $10.3390 /$ su 10030782

[13] Dell'Amico M, Hadjidimitriou S. Innovative Logistics 
Model and Containers Solution for Efficient Last Mile Delivery. Procedia - Social and Behavioral Sciences. 2012;48: 1505-14. DOI: 10.1016/j.sbspro.2012.06.1126

[14] Perboli G, Rosano M, Gobbato L. Parcel delivery in urban areas: Opportunities and threats for the mix of traditional and green business models. Transportation Research Part C. 2016;99(January): 19-36. DOI: 10.1016/ j.trc.2019.01.006

[15] Juan AA, Mendez CA, Faulin J, De Armas J, Grasman SE. Electric vehicles in logistics and transportation: A survey on emerging environmental, strategic, and operational challenges. Energies. 2016;9: 86. DOI: 10.3390/ en9020086

[16] Kosovac A, Ferizović A. Impact of electric vehicle usage in the City Logistic center of Sarajevo. Suvremeni Promet - Modern Traffic. 2017;37(5-6): 223-9.

[17] Juan AA, Goentzel J, Bektaş T. Routing fleets with multiple driving ranges: Is it possible to use greener fleet configurations? Applied Soft Computing Journal. 2014;21: 84-94. DOI: 10.1016/j.asoc.2014.03.012

[18] Kosovac A, Ferizović A. Mathematical Model Of Measurement Of Positive Effects On The Application Of Electrical Vehicles In City Logistics. In: $5^{\text {th }}$ International Conference on Road and Rail Infrastructure, CETRA 2018. Zadar; 2018. p. 1533-40. DOI: 10.5592/CO/CETRA.2018.643

[19] Muñoz-Villamizar A, Montoya-Torres JR, Faulin J. Impact of the use of electric vehicles in collaborative urban transport networks: A case study. Transportation Research Part D: Transport and Environment. 2017;50: 40-54. DOI: 10.1016/j.trd.2016.10.018

[20] Tiwapat N, Pomsing C, Jomthong P. Last Mile Delivery: Modes, Efficiencies, Sustainability, and Trends. In: 2018 $3^{\text {rd }}$ IEEE International Conference on Intelligent Transportation Engineering, ICITE 2018; 2018. p. 313-7. DOI: 10.1109/ICITE.2018.8492585

[21] Lemke J, Iwan S, Korczak J. Usability of the Parcel Lockers from the Customer Perspective - The Research in Polish Cities. Transportation Research Procedia. 2016;16(March): 272-87. DOI: 10.1016/ j.trpro.2016.11.027

[22] Ulmer MW, Streng S. Same-Day delivery with pickup stations and autonomous vehicles. Computers and $\mathrm{Op}$ erations Research. 2019;108: 1-19. DOI: 10.1016/j. cor.2019.03.017

[23] Vakulenko Y, Hellström D, Hjort K. What's in the parcel locker? Exploring customer value in e-commerce last mile delivery. Journal of Business Research. 2018;88(June): 421-7. DOI: 10.1016/j.jbusres.2017.11.033

[24] Iwan S, Kijewska K, Lemke J. Analysis of Parcel Lockers' Efficiency as the Last Mile Delivery Solution - The Results of the Research in Poland. Transportation Research Procedia. 2016;12(June 2015): 644-55. DOI: 10.1016/j.trpro.2016.02.018

[25] Verlinde S, Rojas C, Buldeo Rai H, Kin B, Macharis C. E-Consumers and Their Perception of Automated Parcel Stations. In: Taniguchi E, Thompson E. (eds.) City Logistics 3: Towards Sustainable and Liveable Cities; 2018. p. 147-60. DOI: 10.1002/9781119425472.ch8

[26] Boysen N, Schwerdfeger S, Weidinger F. Scheduling last-mile deliveries with truck-based autonomous robots.
European Journal of Operational Research. 2018;271(3): 1085-99. DOI: 10.1016/j.ejor.2018.05.058

[27] Karak A, Abdelghany K. The hybrid vehicle-drone routing problem for pick-up and delivery services. Transportation Research Part C: Emerging Technologies. 2019;102(March): 427-49. DOI: 10.1016/ j.trc.2019.03.021

[28] Kunze O. Replicators, Ground Drones and Crowd Logistics A Vision of Urban Logistics in the Year 2030. Transportation Research Procedia. 2016;19(June): 286-99. DOI: $10.1016 / j$.trpro.2016.12.088

[29] Menouar H, Guvenc I, Akkaya K, Uluagac AS, Kadri A, Tuncer A. UAV-enabled intelligent transportation systems for the smart city: Applications and challenges. IEEE Communications Magazine. 2017;55(3): 22-8. DOI: 10.1109/MCOM.2017.1600238CM

[30] Dorling K, Heinrichs J, Messier GG, Magierowski S. Vehicle Routing Problems for Drone Delivery. IEEE Transactions on Systems, Man, and Cybernetics: Systems. 2017;47(1): 70-85. DOI: 10.1109/TSMC.2016.2582745

[31] Shetty VK, Sudit M, Nagi R. Priority-based assignment and routing of a fleet of unmanned combat aerial vehicles. Computers and Operations Research. 2008;35(6): 1813-28. DOI: 10.1016/j.cor.2006.09.013

[32] Boysen N, Briskorn D, Fedtke S, Schwerdfeger S. Drone delivery from trucks: Drone scheduling for given truck routes. Networks. 2018;72(4): 506-27. DOI: 10.1002/ net. 21847

[33] Kinyua BK. Determinants of outsourcing services as a cost reduction measure in devolved government: a case study of Nairobi city county, Kenya. European Journal of Business and Social Sciences. 2015;4(05): 12-23. Available from: http://www.ejbss.com/recent.aspx-/

[34] Fadile L, El Oumami M, Beidouri Z. Logistics outsourcing: A review of basic concepts. International Journal of Supply Chain Management. 2018;7(3): 53-69.

[35] Digiesi S, Fanti MP, Mummolo G, Silvestri B. Externalities reduction strategies in last mile logistics: A review. In: Proceedings - 2017 IEEE International Conference on Service Operations and Logistics, and Informatics, SOLI 2017; 2017. p. 248-53. DOI: 10.1109/ SOLI.2017.8121002

[36] Kim SJ, Lim H, Park M. Analysing the cost efficiency of parcel distribution networks with changes in demand. International Journal of Urban Sciences. 2014;18(3): 416-29. DOI: 10.1080/12265934.2014.975152

[37] Gevaers R, Van de Voorde E, Vanelslander T. Cost Modelling and Simulation of Last-mile Characteristics in an Innovative B2C Supply Chain Environment with Implications on Urban Areas and Cities. Procedia - Social and Behavioral Sciences. 2014;125:398-411. DOI: 10.1016/j.sbspro.2014.01.1483

[38] Chaabouni F, Dhiaf MM. Logistics outsourcing relationships: Conceptual model. In: 2013 International Conference on Advanced Logistics and Transport, ICALT 2013. 2013. p. 458-63. DOI: 10.1109/ICAdLT.2013.6568502

[39] Zäpfel G, Bögl M. Multi-period vehicle routing and crew scheduling with outsourcing options. International Journal of Production Economics. 2008;113(2):980-96. DOI: 10.1016/j.ijpe.2007.11.011

[40] Hill AV, Hays JM, Naveh E. A Model for Optimal 
Delivery Time Guarantees. Journal of Service Research. 2000;2(3): 254-64. DOI: 10.1177/109467050023003

[41] So KC. Price and Time Competition for Service Delivery. Manufacturing \& Service Operations Management. 2003;2(4): 392-409. DOI: 10.1287/msom.2.4.392.12336

[42] Thakur RK. Assessment Model for Outsourced PickUp and Delivery Operations. PhD thesis. MIT Global SCALE Network. Report number: MIT-2013-12, 2016. Available from: https://dspace.mit.edu/bitstream/handle/1721.1/102052/2013_12_Thakur.pdf

[43] Ülkü MA, Bookbinder JH. Optimal quoting of delivery time by a third party logistics provider: The impact of shipment consolidation and temporal pricing schemes. European Journal of Operational Research. 2012;221(1): 110-7. DOI: 10.1016/j.ejor. 2012.03.021
[44] Zhu W, Ng SCH, Wang Z, Zhao X. The role of outsourcing management process in improving the effectiveness of logistics outsourcing. International Journal of Production Economics. 2017;188(March): 29-40. DOI: 10.1016/j.ijpe.2017.03.004

[45] Han HS, Lee JN, Seo YW. Analyzing the impact of a firm's capability on outsourcing success: A process perspective. Information and Management. 2008;45(1): 31-42. DOI: 10.1016/j.im.2007.09.004

[46] Kin B, Spoor J, Verlinde S, Macharis C, Van Woensel T. Modelling alternative distribution set-ups for fragmented last mile transport: Towards more efficient and sustainable urban freight transport. Case Studies on Transport Policy. 2018;6(1): 125-32. DOI: 10.1016/j.cstp. 2017.11.009 